Ks. Piotr SZCZUR

(Lublin, KUL)

\title{
CELE CHRZEŚCIJAŃSKIEGO MAŁŻEŃSTWA W NAUCZANIU JANA CHRYZOSTOMA
}

W dyskusji na temat wartości małżeństwa, która prowadzona była w czasach starożytności pogańskiej, padały diametralnie odmienne głosy․ Część filozofów oceniało małżeństwo negatywnie. Należy wymienić tu Demokryta, który odrzucał małżeństwo jako instytucję, która niesie ze sobą wiele uciążliwości i obowiązków odciągających człowieka od ważniejszych spraw²; podobny stosunek do małżeństwa miał Epikur ${ }^{3}$. Teofrast, przedstawiciel perypatetyków, miał twierdzić w zaginionym dziele De nuptiis, że mędrzec nie powinien się żenić, ponieważ małżeństwo przeszkadza w poświęceniu się filozofii ${ }^{4}$. Wcześniejsi przedstawiciele stoików również uważali, że nie należy się żenićs Neopitagorejczycy ${ }^{6}$ i neoplatończycy ${ }^{7}$ także negatywnie ustosunkowywali się do instytucji małżeństwa. Ich stanowisko wynikało z dualistycznej koncepcji, według której ciało należało poddawać surowej ascezie, aby dusza mogła być wolna i całkowicie oddawać się kontemplacji. Sekstus Pitagorejczyk w swoich Sentencjach stwierdza, że mędrzec nie powinien się żenić, a jedyną racją dla istnienia małżeństwa jest prokreacja ${ }^{8}$.

Natomiast część myślicieli oceniała małżeństwo pozytywnie. Zdaniem Platona małżeństwo i związane z nim rodzenie dzieci pozwala trwać gatunkowi ludzkiemu i jako takie zasługuje na ocenę pozytywną9. Również późniejsi stoicy doceniali moralną wartość małżeństwa i wskazywali na walor prokreacji, która zapewnia ciągłość istnienia rodzin i całego państwa. Na takie,

\footnotetext{
${ }^{1}$ Szerzej na ten temat zob. P. Nehring, Dlaczego dziewictwo jest lepsze niż matżeństwo?, Toruń 2005, 9-12.

${ }^{2}$ Por. Clemens Alexandrinus, Stromata II 23, 138, 3.

${ }^{3}$ Por. tamże 138, 4.

${ }^{4}$ Por. Hieronymus, Adversus Jovinianum I 47.

${ }^{5}$ Por. Clemens Alexandrinus, Stromata II 23, 138, 5; M. Schofield, The Stoic idea of the city, Cambridge 1991, 119-127 (Descending to marriage).

${ }^{6}$ Por. Philostratus, Vita Apolonii I 13.

${ }^{7}$ Por. Plotinus, Enneadae III 6, 5.

${ }^{8}$ Por. Sextus Pythagoreus, Sententiae 230b.

${ }^{9}$ Por. Plato, Leges IV $721 \mathrm{C}$.
} 
wspomniane tu, polityczne znaczenie małżeństwa wskazywał m.in. Hierokles żyjący w II w. po Chrystusie ${ }^{10}$. Epiktet twierdził, że ludzie powinni się żenić, gdyż prokreacja, którą nierozerwalnie wiązał z małżeństwem, jest wypełnieniem ludzkiego powołania ${ }^{11}$. Nietrudno zauważyć, że ci ze starożytnych myślicieli, którzy pozytywnie oceniali małżeństwo, wskazywali przede wszystkim na wartość prokreacji.

Ojcowie Kościoła w nauczaniu na temat małżeństwa i rodziny czerpali z dwóch zasadniczych źródeł: Pisma Świętego oraz z dorobku starożytnych myślicieli pogańskich. Nie ulega wątpliwości, że Pismo Święte pozytywnie ocenia instytucję małżeństwa. W ujęciu autorów biblijnych jednym z głównych jego celów było zrodzenie potomstwa, będącego Bożym darem i błogosławieństwem. Dlatego małżonkowie zabiegali o to, by mieć dużo dzieci. Nie dziwi zatem fakt, że większość Ojców Kościoła, mówiąc o wartości małżeństwa wskazywała przede wszystkim na walor prokreacji, która w ich wykładzie stała się pierwszym i podstawowym celem małżeństwa. W niniejszych rozważaniach postaramy się odpowiedzieć na pytanie: jak Jan Chryzostom przedstawiał cele chrześcijańskiego małżeństwa?

Aby odpowiedzieć na to pytanie należy odwołać się do antropologii i eklezjologii Antiocheńczyka. Nasz Autor podkreśla, że człowiek został stworzony

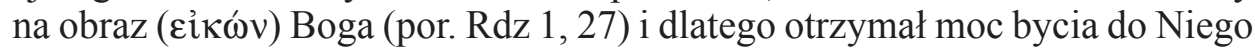
podobnym, przez nabywanie boskich cech. Antiocheńczyk rozumie przez to możliwość stawania się łagodnym, kochającym, łaskawym, twórczym i peł-

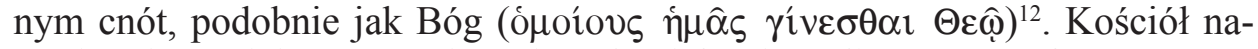

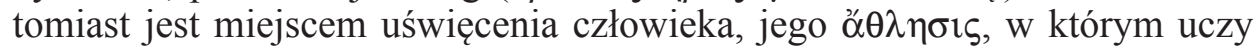
się on, jak stać się podobnym do Boga. Te założenia sprawiają, że złotousty kaznodzieja nieco inaczej (w stosunku do innych pisarzy chrześcijańskich) przedstawia cele chrześcijańskiego małżeństwa.

1. Zachowanie czystości. W ujęciu Jana Chryzostoma małżeństwo zostało ustanowione przede wszystkim po to, by człowiek mógł trwać w czystości i wstrzemięźliwości oraz by ustrzec go przed rozpustą i nierządem ${ }^{13}$. Jeżeli

\footnotetext{
${ }^{10}$ Por. Stobaeus, Anthologium IV 604, 26.

${ }^{11}$ Por. Epictetus, Dissertationes III 7, 26.

${ }^{12}$ Por. Joannes Chrysostomus, In Genesim hom. 9, 3, PG 53, 78.

${ }^{13}$ Por. Joannes Chrysostomus, In epistulam I ad Corinthios hom. 12, 6, PG 61, 104; De virginitate 19, 1, ed. H. Musurillo, SCh 125, Paris 1966, 156; 39, 3, SCh 125, 230; In illud: „Propter fornicationes unusquisque suam uxorem habeat" 3, PG 51, 213; Quales ducendae sint uxores 5, PG 51, 232; A. Moulard, Saint Jean Chrysostome, le défenseur du mariage et l'apôtre de la virginité, Paris 1923, 72-76; P. Rentinck, La cura pastorale in Antiochia nel IV secolo, Roma 1970, 262-266; C. Militello, Donna e Chiesa. La testimonianza di Giovanni Crisostomo, Palermo 1985, 134; L. Dattrino, Il matrimonio nel pensiero di San Giovanni Crisostomo, Roma 2002, spec. 25-35 (I fini del matrimonio); S. Longosz, Antykoncepcja i aborcja w ocenie św. Jana Chryzostoma, RT 54 (2007) z. 10, 286.
} 
ten cel nie zostanie zrealizowany, to małżeństwo staje się bezwartościowe ${ }^{14}$. Jednak owego trwania w czystości nie należy rozumieć jako rezygnację z pożycia płciowego, gdyż małżonkowie między innymi przez współżycie mają stać się ,jednym ciałem” (por. Rdz 2, 24; Mt 19, 5. 6; Mk 10, 8), by w ten sposób realizować Boży zamysł jedności małżeńskiej.

Idealny model wieku małżonków obowiązujący w IV wieku nie zmienił się od czasów Arystotelesa ${ }^{15}$. Najbardziej wskazany wiek zawarcia małżeństwa przez mężczyzn wynosił około 37 lat (lub nieco mniej), natomiast przez kobiety około 18 lat ${ }^{16}$. W kontekście konieczności utrzymywania w ryzach pożądliwości ${ }^{17}$ Jan Chryzostom protestował przeciw temu zwyczajowi i nalegał, aby małżeństwa zawierać wcześniej ${ }^{18}$. Przyczyną takiej postawy było rozumienie małżeństwa jako środka zabezpieczającego młodych mężczyzn przed nierządem ${ }^{19}$, co stawało się też jednym z elementów chrystianizacji społeczeństwa ${ }^{20}$. Święty Jan Chryzostom wyjaśnia, że małżeństwo nie jest dobrem samym w sobie. Jego dobro polega na tym, że jest środkiem przeciwko cudzołóstwu i rozpuście oraz przeciw grzechom przeciwnym naturze ${ }^{21}$.

Antiocheńczyk podkreśla, że nie tylko mnisi, lecz również chrześcijanie żyjący w małżeństwie są wezwani do praktykowania czystości: prawa Chrystusa odnoszą się do wszystkich ludzi, nie tylko do mnichów. Małżeństwo jest środkiem, z którym Bóg wychodzi naprzeciw ludzkiej słabości, aby uwolnić człowieka od nieczystości i ułatwić praktykowanie czystości oraz osiągnięcie świętości ${ }^{22}$. Chryzostom twierdzi, że mężczyźnie trudniej jest zapanować nad pożą-

${ }^{14}$ Por. Joannes Chrysostomus, In Matthaeum hom. 59, 7, PG 58, 583, tłum. A. Baron, ŹMT 23, Kraków 2001, 224: „[...] korzyścią małżeństwa jest zachowanie ciała w czystości, \{i jeśli tak nie jest, to nie ma żadnej korzyści z małżeństwa\}”; In illud: „Propter fornicationes unusquisque suam uxorem habeat” 3, PG 51, 212-213; Expositio in Psalmum 43, 9, PG 55, 181.

${ }^{15}$ Por. Aristoteles, Politica VII 14, 6 (1335a), thum. L. Piotrowicz, w: Arystoteles, Polityka, Wrocław 2005, 339: „Dlatego wiekiem odpowiednim do małżeństwa jest dla dziewcząt, mniej więcej 18 lat, dla mężczyzn 37 lub niewiele mniej”.

${ }^{16}$ Szerzej na temat wieku mężczyzn zawierających związek małżeński por. R.P. Saller, Men's age at marriage and its consequences in the Roman Family, CPh 82 (1987) 21-34.

${ }^{17}$ Por. Rentinck, La cura pastorale in Antiochia, s. 252.

${ }^{18}$ Por. Joannes Chrysostomus, De inani gloria et de educandis liberis 81-82, ed. A.M. Malingrey, SCh 188, Paris 1972, 188-190.

${ }^{19}$ Por. Joannes Chrysostomus, In illud: „Propter fornicationes unusquisque suam uxorem habeat" 2, PG 51, 210.

${ }^{20}$ Por. A. Natali, Mariages chrétiens à Antioche au IVE siècle, w: Sociabilité, Pouvoirs et Société. Actes du Colloque (Rouen, 24/26 Novembre 1983), ed. F. Thelamon, Rouen 1987, 112.

${ }^{21}$ Por. Joannes Chrysostomus, De virginitate 39, 2, SCh 125, 230; 9, 1, SCh 125, 120; 27, 3-4, SCh 125, 180; 33-34, 1, SCh 125, 198-200; Adversus oppugnatores vitae monasticae III 8, PG 47, 360; In epistulam ad Romanos hom. 4, 1-3, PG 60, 417-420; In epistulam I ad Corinthios hom. 19, 1, PG 61, 151.

${ }^{22}$ Por. Joannes Chrysostomus, In Matthaeum hom. 7, 7, PG 57, 81, thum. J. Krystyniacki, ŹMT 18, Kraków 2000, 100: „Wszystkie prawa mamy przecież wspólne z pustelnikami oprócz 
dliwością, ale żona, dana mężczyźnie jako towarzyszka, może pomóc mężowi w kontrolowaniu instynktów ${ }^{23}$. Pomimo tego, że między mężczyzną a kobietą istnieją duże różnice, to jednak w odniesieniu do zachowywania czystości nie ma między nimi różnicy: obydwoje powinni żyć w jednakowej czystości ${ }^{24}$.

Czystość małżonków jest warunkiem koniecznym do zachowania i pogłębienia miłości małżeńskiej: niepowściągliwy mężczyzna nie może kochać swojej żony; również mężczyzna wstrzemięźliwy przez zaniedbywanie swej żony lub pogardzanie nią dowodzi braku miłości, a przecież z miłości rodzi się wszelkie dobro' ${ }^{25}$.

Według św. Jana Chryzostoma akt małżeński sam w sobie nie jest grzechem nieczystości: pragnienie zjednoczenia cielesnego jest naturalnym pragnieniem, wszczepionym przez Boga w ludzką naturę ${ }^{26}$. Dlatego zło grzechu cudzołóstwa nie wynika z cielesnego zjednoczenia; jeżeli tak by było, także akt małżeński byłby nieczysty. Zło cudzołóstwa polega na niesprawiedliwości względem drugiego człowieka, który zostaje skrzywdzony w tym, co jest dla niego najcenniejsze ${ }^{27}$. Natomiast stosunki między małżonkami, chociaż przynoszą przyjemność i satysfakcję, to jednak nie przeszkadzają w życiu w czystości ${ }^{28}$. Co więcej, nasz Autor dopuszcza korzystanie z tej radości małżeństwa aż do starości ${ }^{29}$.

W homiliach na temat Księgi Rodzaju Chryzostom dotyka też historii Onana, jednak bez nastawania na jego grzech ${ }^{30}$. Najwidoczniej problem ten

małżeństwa, ale i w tym względzie Paweł nakazuje naśladować ich we wszystkim"; De virginitate 19, 2, SCh 125, 158; In Genesim hom. 59, 3, PG 54, 517-518.

${ }^{23}$ Por. Joannes Chrysostomus, In illud: ,, Vidi Dominum” hom. 3, 3, ed. J. Dumortier, SCh 277 , Paris 1981, 119; 4, 2, SCh 277, 149; In Matthaeum hom. 7, 7, PG 57, 81-82; In epistulam II ad Thessalonicenses hom. 5, 5, PG 62, 499; De virginitate 52, 7, SCh 125, 296-298.

${ }^{24}$ Por. Joannes Chrysostomus, In illud: „Propter fornicationes unusquisque suam uxorem habeat" 4, PG 51, 214; 5, PG 51, 218; In epistulam I ad Corinthios hom. 19, 1, PG 61, 152.

${ }^{25}$ Por. Joannes Chrysostomus, In illud: „Propter fornicationes unusquisque suam uxorem habeat" 4, PG 51, 215; zob. J.C.Guy - F. Refoulé, Chrétiennes des premiers temps, Paris 1965, 67.

${ }^{26}$ Por. Joannes Chrysostomus, In epistulam ad Titum hom. 5, 2, PG 62, 689, thum. T. Sinko, w: Św. Jan Złotousty, Homilie na listy pasterskie św. Pawła i na List do Filemona, Kraków 1949, 348: „żądza cielesna powstaje przymusowo, [...] jest wrośnięta w naturę”; In epistulam ad Ephesios hom. 2, 3, PG 62, 20.

${ }^{27}$ Por. Joannes Chrysostomus, In epistulam ad Titum hom. 3, 3, PG 62, 682, tłum. T. Sinko, s. 334: „Nierządnik (ó đópvoৎ) jest nieczysty nie przez spółkowanie, lecz przez sposób, w jaki krzywdzi niewiastę. I siebie samych krzywdzą ci, którzy niewiastę czynią wspólną własnością i obalają prawa natury. Powinna bowiem była należeć do jednego. [...] Na tym polega niesprawiedliwość i dlatego nierząd jest zły"..

${ }^{28}$ Por. Joannes Chrysostomus, In illud: „Propter fornicationes unusquisque suam uxorem habeat" 5, PG 51, 217; In epistulam I ad Corinthios hom. 19, 2, PG 61, 154; 19, 6, PG 61, 160.

${ }^{29}$ Por. Joannes Chrysostomus, In epistulam ad Titum hom. 5, 2, PG 62, 689, tłum. T. Sinko, s. 348: ,i kto obcował z żoną prawnie, nikt by go nie mógł zganić aż do starości”.

${ }^{30}$ Por. Joannes Chrysostomus, In Genesim hom. 62, 1, PG 54, 533; zob. Longosz, Antykoncepcja i aborcja, s. 281-282. 
nie przedstawiał się jako ,palący”, lub też był zbyt delikatny, aby był poruszany publicznie.

W literaturze patrystycznej dość często spotykamy zalecenia do respektowania niektórych okresów wstrzemięźliwości w pożyciu małżeńskim. Świadectwa patrystyczne - zwłaszcza powiązane ze środowiskiem aleksandryjskim - wskazują, że czasem wstrzemięźliwości seksualnej była najczęściej niedziela, różne święta i uroczystości kościelne, okres Wielkiego Postu, a nawet dzień przed przyjęciem Komunii świętej ${ }^{31}$. Jan Chryzostom nie mówi o takich zaleceniach. Wprawdzie wspomina, że w Antiochii niektórzy chrześcijanie powstrzymują się od współżycia małżeńskiego przed liturgią, jednak nie mówi o wstrzemięźliwości absolutnej jako o ideale małżeństwa ${ }^{32}$. W tym kontekście Chryzostom wyjaśniał, że zespolenie małżonków w akcie małżeńskim nie stanowi przeszkody dla praktykowania modlitwy. Taką przeszkodę stanowi grzech, a przecież akt małżeński nie jest on grzechem, więc nie jest przeszkodą dla praktykowania modlitwy ${ }^{33}$.

Małżonkowie są zobowiązani do oddawania sobie „długu” małżeńskiego: mąż i żona nie mogą już w sposób wolny dysponować własnym ciałem, gdyż to współmałżonek jest panem ciała ${ }^{34}$. We wstrzemięźliwości małżonkowie mogą żyć tylko za obopólną zgodą. Jeżeli żona chce praktykować wstrzemięźliwość, a mąż nie chce, żona musi podążać za mężem ${ }^{35}$. Żona, która odmawia współżycia, także wówczas, gdy robi to z powodów ascetycznych, staje się odpowiedzialna za ewentualne cudzołóstwo swojego męża ${ }^{36}$. Złotousty ka-

${ }^{31}$ Por. Dionysius Alexandrinus, Epistula ad Basylidem 2-3, tłum. S. Kalinkowski, ŹMT 49, Kraków 2009, 4; Athanasius Alexandrinus, Epistula ad Antiochum 5, tłum. S. Kalinkowski, ŹMT 49, 30-31; Timotheus Alexandrinus, Responsiones 5-7 i 13, thum. S. Kalinkowski, ŹMT 49, 92 i 94; zob. Guy - Refoulé, Chrétiennes des premiers temps, s. 50; J. Gaudemet, L'Église dans l'Empire Romain (IVE-V siècles), Paris 1958, 551-552.

${ }^{32}$ Por. Joannes Chrysostomus, In epistulam ad Titum hom. 5, 2, PG 62, 690, thum. T. Sinko, s. 348: „A o pieniądzach także Chrystus wiele dał rozkazów, aby unikać tej zarazy; a o powstrzymywaniu się od żony nie mówił".

${ }^{33}$ Por. Joannes Chrysostomus, In Matthaeum hom. 51, 5, PG 58, 516, ŹMT 23, 120: „Nie masz odwagi modlić się po współżyciu z własną żoną, chociaż nie ma w tym nic złego [...]. Jeśli wstając z niepokalanego łoża małżeńskiego nie ważysz się przystąpić do modlitwy"; In epistulam ad Titum hom. 3, 4, PG 62, 681; In epistulam I ad Corinthios hom. 19, 2, PG 61, 153.

${ }^{34}$ Por. Joannes Chrysostomus, In epistulam I ad Corinthios hom. 19, 1, PG 61, 152; In illud: „Propter fornicationes unusquisque suam uxorem habeat” 4, PG 51, 214; De virginitate 41, 2, SCh $125,238$.

${ }^{35}$ Por. Joannes Chrysostomus, In epistulam I ad Corinthios hom. 19, 1, PG 61, 152; De virginitate 38, 1, SCh 125, 224; 47, 5, SCh 125, 270.

${ }^{36}$ Por. Joannes Chrysostomus, In Matthaeum hom. 86, 4, PG 58, 768, ŹMT 23, 497: „Chrystus przykazał przez Pawła, aby żona nie opuszczała męża i aby sobie wzajemnie nie odmawiali powinności, chyba że za obopólnym zezwoleniem (por. 1Kor 7, 5). Jednak niektóre żony oddzielają się od swych mężów z umiłowania wstrzemięźliwości (por. 1Kor 7, 5), jakby spełniały pobożny czyn, i tak popychają ich ku nierządowi"; De virginitate 48, 1, SCh 125, 270; In epistulam I ad Corinthios hom. 19, 1, PG 61, 153. 
znodzieja podkreśla, że małżonkowie przede wszystkim powinni troszczyć się o harmonię wspólnego życia ${ }^{37}$. Jeżeli harmonię tę poświęca się dla praktykowania wstrzemięźliwości, wówczas wstrzemięźliwość nie będzie miała żadnej wartości, ponieważ jej zachowywanie może wywoływać kłótnie i awantury. Wstrzemięźliwość zatem nie jest ideałem samym w sobie, lecz jest służbą podporządkowaną miłości małżeńskiej.

2. Zrodzenie potomstwa. Małżeństwo służy też zrodzeniu i wychowaniu dzieci $^{38}$. Jednak prokreacja w nauczaniu Chryzostoma jest drugoplanowym celem małżeństwa ${ }^{39}$. Bóg ustanowił zrodzenie potomstwa jako jeden z celów małżeństwa $\mathrm{z}$ dwóch powodów: 1) żeby dać ludziom pocieszenie, że ich egzystencja nie kończy się wraz ze śmiercią, lecz że mogą ją przedłużyć przez zrodzenie potomstwa; 2) aby zapewnić ciągłość istnienia rodzaju ludzkiego ${ }^{40}$. Złotousty kaznodzieja podkreśla, że Bóg wybrał małżeństwo jako sposób rozmnażania rodzaju ludzkiego, chociaż mógłby wybrać inną drogę pomnażania ludzi, o czym świadczy pokolenie Adama i Ewy oraz istnienie aniołów ${ }^{41}$. W aktualnym stanie małżeństwo ma na celu prokreację, ale cel ten nie wynika, zdaniem Chryzostoma, z natury małżeństwa, lecz z nakazu Bożego, aby ludzie wzrastali, rozmnażali się i zaludnili ziemię (por. Rdz 1, 28) ${ }^{42}$.

${ }^{37}$ Por. Joannes Chrysostomus, In epistulam I ad Corinthios hom. 19, 1, PG 61, 153.

${ }^{38}$ Por. Joannes Chrysostomus, In epistulam ad Ephesios hom. 20, 8, PG 62, 146. J. Naumowicz (Jan Chryzostom - życie i działalność, w: Św. Jan Chryzostom, O matżeństwie, wychowaniu dzieci i ascezie, BOK 19, Kraków 2000, 13) podkreśla, że 20. homilia na List św. Pawła do Efezjan „stanowi kodeks moralny dla małżonków i ukazuje ideał małżeństwa chrześcijańskiego”. Wypowiadając się na temat celów małżeństwa Antiocheńczyk stwierdza (In illud: „Propter fornicationes unusquisque suam uxorem habeat” 3, PG 51, 213, przekład własny): „Dwa są powody, dla których zostało ustanowione małżeństwo: abyśmy byli czyści i zostali ojcami. Jednak z tych dwóch powodów ważniejsza jest czystość. Po tym jak na świecie pojawiło się pożądanie, zostało także ustanowione małżeństwo, aby usunąć pożądanie i doprowadzić mężczyznę do zadowolenia się jedną kobietą. Ponieważ rodzenie dzieci nie jest skutkiem małżeństwa, lecz słowa Boga, który mówi: «Bądźcie płodni i rozmnażajcie się, abyście zaludnili ziemię» (Rdz 1, 28). Świadczą o tym ci, którzy żyli w małżeństwie i nie stali się ojcami. Z tego powodu główną przyczyną [zawierania małżeństwa], zwłaszcza obecnie, gdy nasz rodzaj rozprzestrzeniony jest po całej zamieszkałej ziemi, jest czystość"; zob. Rentinck, La cura pastorale in Antiochia, s. 266-268.

${ }^{39}$ Por. Joannes Chrysostomus, In illud: „Propter fornicationes unusquisque suam uxorem habeat” 3, PG 51, 213; Militello, Donna e Chiesa, s. 137: „Per Crisostomo, come generalmente per la teologia orientale, l'evento procreativi è secondario".

${ }^{40}$ Por. Joannes Chrysostomus, In Joannem hom. 19, 1, PG 59, 120; In illud: „Propter fornicationes unusquisque suam uxorem habeat" 3, PG 51, 213.

${ }^{41}$ Por. Joannes Chrysostomus, De virginitate 14, 6, SCh 125, 142-144; zob. Moulard, Saint Jean Chrysostome, s. 64-65.

${ }^{42}$ Por. Joannes Chrysostomus, In illud: „Propter fornicationes unusquisque suam uxorem habeat" 3, PG 51, 213; De vieginitate 15, 1, SCh 125, 144. 
Analizując teksty Księgi Rodzaju, Antiocheńczyk zauważa, że dopiero po grzechu pierworodnym i wygnaniu z raju nastąpiło współżycie płciowe ${ }^{43}$, skutkiem czego było zrodzenie potomstwa ${ }^{44}$. Podkreśla też, że Pismo Święte nie łączy rodzenia dzieci z istotą małżeństwa, na co wskazuje wypowiedź Ewy po urodzeniu Kaina: „Otrzymałam mężczyznę od Pana” (Rdz 4, 1). Dziecko jest zatem darem Boga ${ }^{45}$. Złotousty kaznodzieja nie uważał więc prokreacji za istotę małżeństwa ${ }^{46}$, tym bardziej, iż przywoływał postaci małżonków, którzy - żyjąc przecież w małżeństwie - nie posiadali dzieci ${ }^{47}$, a ustanowienie małżeństwa (związanego z płodzeniem dzieci) łączył z grzechem pierwszych ludzi ${ }^{48}$.

W rozważaniach na temat seksualności człowieka złotousty Kaznodzieja podkreśla, że pożądanie jest czymś naturalnym ${ }^{49}$ i właściwym naturze ludzkiej, dlatego wszyscy ludzie, nawet osoby unikające kontaktów z kobietami ${ }^{50}$, odczuwają żar pożądania ${ }^{51}$. Wyjaśnia, że pożądanie nie zostało dane dla grzechu, lecz dla spłodzenia dzieci. Prokreacja wpisuje się w misterium miłości małżeńskiej: jeżeli żona i mąż pozostają dwoje, i nie łączą się z sobą, to nie rozmnażają się, natomiast jeżeli jednoczą się i tworzą jedno ciało, ich zjednoczenie jest płodne i czyni możliwym powstanie nowego życia ${ }^{52}$. Czasami dziecko pełni funkcję mostu pomiędzy rodzicami, wzmacnia ich zjednoczenie: już nie są dwoje, ale troje, którzy tworzą jedno ciało ${ }^{53}$. Bóg wybrał tę drogę prokreacji, żeby między ludźmi nawiązała się więź miłości.

${ }^{43}$ Por. Joannes Chrysostomus, In Genesim hom. 18, 4, PG 53, 153; zob. Longosz, Antykoncepcja i aborcja, s. 287.

${ }^{44}$ Por. Joannes Chrysostomus, In Genesim hom. 18, 4, PG 53, 153; zob. Militello, Donna e Chiesa, s. 128.

${ }^{45}$ Por. Joannes Chrysostomus, In Genesim hom. 18, 4, PG 53, 154; De Anna sermo 1, 4, PG 54,639 .

${ }^{46}$ Por. M. Dmitruk, Obyczaje weselne i pogrzebowe chrześcijan w świetle duszpasterskiej działalności św. Jana Chryzostoma, VoxP 21 (2001) t. 40-41, 265.

${ }^{47}$ Por. Joannes Chrysostomus, In illud: „Propter fornicationes unusquisque suam uxorem habeat" 3, PG 51, 213.

${ }^{48}$ Por. tamże, PG 51, 214; In Genesim hom. 18, 4, PG 53, 153; In Genesim sermo 4, 1, PG 54, 596; zob. Militello, Donna e Chiesa, s. 130.

${ }^{49}$ Por. Joannes Chrysostomus, In Matthaeum hom. 17, 1, PG 57, 256, ŹMT 18, 215: „Jakkolwiek zarówno gniew, jak i pożądliwość są nam wrodzone i zostały w nas wszczepione dla naszego pożytku. Gniew, abyśmy mogli karać złych i poprawiać nieposłusznych. Pożądliwość zaś, abyśmy mogli mieć potomstwo i w ten sposób podtrzymywać nasz gatunek przez następstwo pokoleń”.

${ }^{50}$ Por. Joannes Chrysostomus, In epistulam ad Titum hom. 5, 2, PG 62, 690, thum. T. Sinko, s. 349: „Lecz chociażby kto nie zbliżał się do niewiasty, natura robi swoje i działa”.

${ }^{51}$ Por. Joannes Chrysostomus, In epistulam ad Titum hom. 5, 2, PG 62, 690, thum. T. Sinko, s. 349: „Kto by nigdy nie miał pieniędzy, ten nigdy nie byłby dręczony tą żądzą, bo nic nie czyni tak łapczywym na pieniądze, jak ich posiadanie. Nie tak się rzecz ma z pożądliwością cielesną, ale nawet wielu trzebieńców nie pozbyło się dręczącego ich wewnątrz płomienia, bo pożądliwość leży w innych narządach, włożona do środka przez naturę".

${ }^{52}$ Por. Joannes Chrysostomus, In epistulam ad Colossenses hom. 12, 5, PG 62, 387.

${ }^{53}$ Por. tamże 12, 5, PG 62, 388. 
Należy zaznaczyć, że w świecie antycznym społeczne racje zawierania małżeństwa podkreślały konieczność prokreacji ${ }^{54}$. Z tego powodu bezpłodność, zarówno u mężczyzn jak i u kobiet (chociaż winą przeważnie obarczano kobiety), była postrzegana jako wielkie nieszczęście ${ }^{55}$, ułomność oraz Boska kara lub konsekwencja bliżej nieokreślonej winy ${ }^{56}$. Z przekonaniem tym, panującym nawet $\mathrm{w}$ społeczeństwie chrześcijańskim, Chryzostom polemizował i usiłował wykazać, że chociaż w Starym Testamencie posiadanie dzieci ukazywane jest jako wyraz Bożego błogosławieństwa (por. Pwt 28, 4; Ps 112(111), 1-3), to jednak opisane w nim bezpłodne kobiety, były jeszcze większym znakiem Bożego błogosławieństwa i przygotowywały ludzkość do wiary w dziewicze poczęcie Maryi ${ }^{57}$. Tłumaczył też, że mężczyźni, w przypadku bezpłodności swych żon, nie powinni złościć się na nie, sprawiać im przykrości ${ }^{58}$, ani zabiegać o spłodzenie dzieci poza małżeństwem. Pociesza też kobiety, dla których bezpłodność była wielkim nieszczęściem ${ }^{59}$, zalecając im ufność w Bożą Opatrznośćco ${ }^{6}$ a jako wzór przedstawia im Annę - matkę Samuela (por. $1 \mathrm{Sm} 1)^{61}$.

Posiadanie dzieci jest uważane za upragnione bogactwo. Jedną z trosk młodej żony jest lęk przed bezpłodnością ${ }^{62}$. Jest prawdą, że dzieci często są przyczyną wielu kłopotów, jednak brak dzieci jest o wiele bardziej dotkliwy. Dla małżonków, zarówno dla mężczyzny jak i dla kobiety, nie ma nic bardziej przykrego, jak brak potomstwa ${ }^{63}$. Chociaż Jan Chryzostom nie wspomina o możliwości zaadoptowania sieroty przez bezdzietne małżeństwo, to jednak najprawdopodobniej dopuszcza taką możliwość, gdyż Konstytucje Apostolskie, które zostały zredagowane w czasach jego działalności w Antiochii, wyraźnie wskazują na taką możliwośćct.

${ }^{54}$ Por. Militello, Donna e Chiesa, s. 140.

${ }_{55}^{5}$ Por. Joannes Chrysostomus, In Genesim hom. 38, 2, PG 53, 352; De Anna sermo 1, 4, PG 54, 638; De virginitate 57, 4, SCh 125, 310. Chryzostom zauważa, iż powszechnie wiadomo, że nie ma dla kobiety nic trudniejszego do zniesienia, niż bezpłodność.

${ }^{56}$ Por. Joannes Chrysostomus, In Genesim hom. 49, 2, PG 54, 445.

${ }^{57}$ Por. Joannes Chrysostomus, In Genesim hom. 49, 2-3, PG 54, 445-447.

${ }^{58}$ Por. Joannes Chrysostomus, De Anna sermo 1, 4, PG 54, 639.

${ }^{59}$ Por. Joannes Chrysostomus, De Anna sermo 2, 1, PG 54, 644.

${ }^{60}$ Por. Joannes Chrysostomus, In Genesim hom. 49, 2, PG 54, 445.

${ }^{61}$ Por. Joannes Chrysostomus, De Anna sermo 1, 4, PG 54, 638-639.

${ }^{62}$ Por. Joannes Chrysostomus, De virginitate 57, 4, SCh 125, 310; De sacerdotio III 13, ed. A.M. Malingrey, SCh 272, Paris 1980, 212.

${ }^{63}$ Por. Joannes Chrysostomus, Ad Theodorum lapsum II 5, PG 47, 314; De Anna sermo 2, 1, PG 54, 644; Non esse desperandum 5, PG 51, 368; Ad Stagirium a daemone vexatum II 8, PG 47, 461; zob. D. Gorce, Mariage et perfection chrétienne d'après S. Jean Chrysostome, „Études Carmélitaines" 21 (1936) 269.

${ }^{64}$ Por. Constitutiones Apostolorum IV 1, 1, tłum. S. Kalinkowski, ŹMT 42, 97: „Jeśli młody chrześcijanin, chłopiec lub dziewczynka, straci rodziców, powinien przyjąć go i adoptować któryś $\mathrm{z}$ braci nie mający własnych dzieci”. 
Serca młodych żon nie tylko przepełnione są lękiem przed bezpłodnością, lecz także obawami przed zbyt licznym potomstwem ${ }^{65}$. W tym kontekście Chryzostom wspomina o antykoncepcji i aborcji. Praktyki antykoncepcyjne postrzega jako wystąpienie przeciw prawom natury ${ }^{66}$. Nadmienia, że niektórzy ludzie z powodu np. chciwości, uważali posiadanie dzieci za uciążliwość. $\mathrm{Z}$ tego powodu stosowali różnego rodzaju środki, by zapobiec ich poczęciu:

„Z tej więc przyczyny wielu zostało bezdzietnymi, uczynili naturę niepłodną, nie zabijając narodzonych dzieci, lecz zapobiegając ich poczęciu"67.

Natomiast o aborcji Chryzostom wspomina w kontekście krytyki prostytucji oraz cudzołóstwa. Aborcję nasz Autor uważa za zbrodnię poważniejszą od zwykłego morderstwa, gdyż poczętemu dziecku nie pozwala się nawet na przyjście na świat ${ }^{68}$. Praktykowanie aborcji jest walką z prawami Bożymi i prawami natury. Przez aborcję dziecko, które jest darem Boga i znakiem Jego błogosławieństwa jest odrzucane; zabójstwo nienarodzonego dziecka jest złem, o popełnianie którego niektórzy zabiegają jak o dobro. Łono matki, które jest „źródłem płodności” zamienia się w „kolebkę śmierci”, zaś kobietę, której jednym z najważniejszych zadań jest rodzenie dzieci, czyni się morderczynią własnego potomstwa ${ }^{69}$. Zadania rodziców wobec dzieci nie ograniczają się tylko do prokreacji, ale są kontynuowane przez wychowywanie i edukację dzieci $^{70}$.

3. Wzajemna pomoc. Małżeństwo zostało też ustanowione, aby małżonkowie nawzajem sobie pomagali ${ }^{71}$. Ta wzajemna pomoc powinna odnosić się do wszystkich wymiarów i aspektów życia ludzkiego. Antiocheńczyk akcentuje, że człowiek ze swojej natury jest słaby i ograniczony, dlatego zostało mu dane małżeństwo, ażeby jedna ze stron mogła uzupełniać braki drugiej strony $^{72}$.

${ }^{65}$ Por. Joannes Chrysostomus, De virginitate 57, 4, SCh 125, 310.

${ }^{66}$ Por. Longosz, Antykoncepcja i aborcja, s. 287.

${ }^{67}$ Joannes Chrysostomus, In Matthaeum hom. 28, 5, PG 57, 357, ŹMT 18, 345.

${ }^{68}$ Por. Aristoteles, Politica VII 14, 10 (1335b); Joannes Chrysostomus, In epistulam ad Romanos hom. 24, 4, PG 60, 626-627, thum. T. Sinko, w: Św. Jan Chryzostom, Homilie na List św. Pawła do Rzymian, t. 2, Kraków 1998, 379: „Czy zauważyłeś, że z pijaństwa rodzi się porubstwo, z porubstwa cudzołóstwo, z cudzołóstwa morderstwo, a raczej coś gorszego; nie wiem nawet, jak to nazwać. Wszak nie zabija, lecz nawet urodzić mu się nie pozwala".

${ }^{69}$ Por. Joannes Chrysostomus, In epistulam ad Romanos hom. 24, 4, PG 60, 626-627, thum. T. Sinko, s. 379: „Dlaczego obrażasz dar Boży; walczysz z Jego prawami; o to, co jest przekleństwem, zabiegasz jak o błogosławieństwo; źródło płodności czynisz kolebką śmierci, a niewiastę, przeznaczoną do płodzenia potomstwa, przygotowujesz do morderstwa?"

${ }^{70}$ Por. B.H. Vandenberghe, Saint Jean Chrysostome et la Parole de Dieu, Paris 1961, 138-142; Rentinck, La cura pastorale in Antiochia, s. 22-29.

${ }^{71}$ Por. Rentinck, La cura pastorale in Antiochia, s. 274-277.

${ }^{72}$ Por. Joannes Chrysostomus, In Joannem hom. 19, 1, PG 59, 120. 
Małżonkowie muszą pomagać sobie, zwłaszcza w dążeniu do doskonałości: dom musi być miejscem ćwiczenia się w cnotach, miejscem, w którym żona i mąż wspierają się wzajemnie, aby lepiej żyć i praktykować cnoty ${ }^{73}$. Mąż, jako głowa żony, ma za zadanie nauczanie żony w sprawach duchowych i w praktykowaniu cnót. Chryzostom zaleca przyszłym mężom poprawianie swych żon, szczególnie na początku małżeństwa, kiedy młode żony mają jeszcze dużo szacunku wobec mężów i są bardziej wrażliwe na ich upomnienia ${ }^{74}$. Jeżeli mąż jest pogodny i skromny, to żona może z tego wiele skorzystać ${ }^{75}$. Również żona, przez słowa i przykład życia, może pomagać swojemu mężowi. W ten sposób wspólnie będą mogli wzrastać $\mathrm{w}$ cnotach $^{76}$. Jeśli małżonkowie wzajemnie się upominają, poprawiają i sobie przebaczają, to wówczas tworzy się prawdziwa rodzina chrześcijańska ${ }^{77}$.

Chryzostom uważa, że najważniejszą cnotą życia rodzinnego jest pokój i zgoda między żoną a mężem ${ }^{78}$. Ta zgoda wynika z prawdziwej miłość małżeńskiej, która jest zjednoczeniem życia, zjednoczeniem duchowym, w którym żona i mąż mają naprawdę jednego ducha i są jednym ciałem ${ }^{79}$. Według porządku natury, mężczyzna i kobieta są stworzeni dla siebie nawzajem, i żadna inna relacja nie jest dla małżeństwa tak fundamentalna i niezbędna ${ }^{80}$. Dlatego też św. Jan Chryzostom zachęca mężów, żeby miłość małżeńską stawiali ponad każdą inną przyjaźnią i preferowali towarzystwo żon, a nie przyjaciół; zamiast szukać zabawy w teatrze, powinni szukać szczęścia w domu, w towarzystwie żony ${ }^{81}$.

${ }^{73}$ Por. tamże 47, 5, PG 59, 270; In Matthaeum hom. 11, 8, PG 57, 201-202; 73, 4, PG 58, 677; De decem millium talentorum debitore 2, PG 51, 18-19; De virginitate 75, 1, SCh 125, 358.

${ }^{74}$ Por. Joannes Chrysostomus, In Matthaeum hom. 30, 5, PG 57, 368, ŹMT 18, 361: „Jeśli masz żonę lubiącą się stroić, przepadającą i uganiającą się za kosmetykami, skłonną do zbytków, gadatliwą i głupią, [...] niech jej mąż stara się usilnie na wszelki sposób ją poprawić. Jakże sprawi, by się poprawiła? Tak, że nie wszystko nakaże jej od razu, ale najpierw odmieni rzeczy drobniejsze, do których nie jest zbyt przywiązana"; Adversus Judaeos 4, 3, PG 48, 860, tłum. J. Iluk, ŹMT 41, 134: „Pełnij więc rolę nauczyciela, opiekuna, zwierzchnika zachęcającego do pobożności”; In epistulam II ad Thessalonicenses hom. 5, 5, PG 62, 499; In epistulam ad Ephesios hom. 20, 8, PG 62, 146.

${ }^{75}$ Por. Joannes Chrysostomus, In epistulam II ad Thessalonicenses hom. 5, 4, PG 62, 498.

${ }^{76}$ Por. Joannes Chrysostomus, In Joannem hom. 61, 3, PG 59, 340; De virginitate 47, 1-2, SCh 125, 262-266; zob. Rentinck, La cura pastorale in Antiochia, s. 246.

${ }^{77}$ Por. Joannes Chrysostomus, In epistulam ad Ephesios hom. 20, 5, PG 62, 141.

${ }^{78}$ Por. Joannes Chrysostomus, In epistulam I ad Corinthios hom. 19, 1, PG 61, 153; 26, 8, PG 61, 223.

${ }^{79}$ Por. Joannes Chrysostomus, In Genesim hom. 45, 2-3, PG 54, 416; In epistulam ad Ephesios hom. 20, 9, PG 62, 148; 20, 2, PG 62, 138.

${ }^{80}$ Por. Joannes Chrysostomus, In epistulam ad Ephesios hom. 20, 1, PG 62, 135; Non esse desperandum 6, PG 51, 369; Quales ducendae sint uxores 3, PG 51, 229.

${ }^{81}$ Por. Joannes Chrysostomus, In epistulam ad Ephesios hom. 20, 6, PG 62, 143-144; 20, 8, PG 62, 147; In Matthaeum hom. 37, 7, PG 57, 428, ŹMT 18, 440: „Masz żonę, masz dzieci; cóż rów- 
Małżeństwo powinno też być miejscem formowania cnót moralnych ${ }^{82}$. Dlatego nasz Autor zachęca, aby chrześcijanie w doskonaleniu się naśladowali pilność małych dzieci, z jaką uczą się czytania i pisania. Doskonalenie jest procesem, a nie aktem jednorazowym, dlatego Antiocheńczyk radzi, by najpierw zwracać uwagę na opanowanie ciała, by następnie przejść do doskonalenia duchowego. W cnotach życia chrześcijańskiego należy ćwiczyć się w domu z całą rodziną i wszystkimi domownikami ${ }^{83}$, jednak szczególna rola przypada mężowi, który przede wszystkim powinien troszczyć się o „kształtowanie” rodziny ${ }^{84}$.

Jan Chryzostom jest świadom realiów codzienności i stwierdza, że dom niekoniecznie musi ułatwiać pracę nad sobą. Niekiedy bywają sytuacje, które nie sprzyjają lub wręcz uniemożliwiają postęp duchowy, jednak powstrzymanie się od wybuchu gniewu ${ }^{85}$ i złości w sytuacjach konfliktów domowych tym bardziej pozwala zachować powściągliwość i opanowanie w relacjach oficjalnych $^{86}$. Złotousty kaznodzieja zaleca, aby stopniowo, krok po kroku, eliminować z życia różnego rodzaju wady i ćwiczyć się w praktykowaniu cnót. Życie rodzinne bowiem dostarcza rozmaitych sytuacji, w których można kontynuować proces doskonalenia ${ }^{87}$. Zwraca też uwagę na konieczność zdobywania

nego tej przyjemności? Masz dom, masz przyjaciół; to są przyjemności, które oprócz skromności mają w sobie wielki zysk"; zob. Vandenberghe, Saint Jean Chrysostome, s. 136-138.

${ }^{82}$ Por. Joannes Chrysostomus, In epistulam ad Ephesios hom. 20, 7, PG 62, 144-146.

${ }^{83}$ Por. Joannes Chrysostomus, In Matthaeum hom. 11, 8, PG 57, 201, ŹMT 18, 144: „Ponownie proszę was i zaklinam, naśladujcie przynajmniej pilność małych dzieci w tej sprawie. One uczą się najpierw kształtu liter, potem starają się je rozpoznać rozproszone, i dopiero wtedy przystępują do czytania. I my tak czyńmy: podzieliwszy cnotę na części, nauczmy się najpierw nie przysięgać, następnie nie przysięgać fałszywie, nie złorzeczyć; potem, przystępując do innego wiersza: nie zazdrościć, nie dogadzać ciału, nie oddawać się obżarstwu ani opilstwu, nie być człowiekiem okrutnym ani gnuśnym, abyśmy następnie od tego mogli przejść do rzeczy duchowych, ćwicząc się we wstrzemięźliwości, w umartwianiu brzucha, w opanowaniu pożądliwości zmysłowych, w sprawiedliwości, w przekraczaniu pokusy sławy, w kształtowaniu skromnego i niewyniosłego sposobu myślenia [...]. W tym wszystkim ćwiczmy się w domu, z przyjaciółmi, z żoną i dziećmi”.

${ }^{84}$ Por. Joannes Chrysostomus, In epistulam ad Ephesios hom. 20, 7, PG 62, 144-146.

${ }^{85}$ Por. Joannes Chrysostomus, Catecheses ad illuminandos 2, 3(10), PG 49, 235, thum. W. Kania, w: Św. Jan Chryzostom, Katechezy chrzcielne, oprac. M. Starowieyski, Lublin 1994, 59: „Obraził cię ktoś z domowników i rozgniewał, wybacz mu i zwycięż swój gniew!”

${ }^{86}$ Por. Joannes Chrysostomus, In Matthaeum hom. 11, 8, PG 57, 201, ŹMT 18, 144: „Wielu współdomowników stanie na przeszkodzie takiemu ćwiczeniu: to sługa oburzy, żona rozgniewa, nieposłuszne bądź niesforne dziecko doprowadzi do wzburzenia czy przekleństw. Jeżeli więc teraz w domu, ciągle przez nich prowokowany, powstrzymasz się od wybuchu przekleństwa, z łatwością będziesz mógł i na rynku pozostać niezwyciężony".

${ }^{87}$ Por. Joannes Chrysostomus, In Matthaeum hom. 11, 8, PG 57, 201-202, ŹMT 18, 144-145: „W podobny sposób opanujesz siebie pod względem złorzeczenia: nie złorzecząc żonie, ani słudze, ani nikomu innemu w domu. Nie rzadko bowiem żona, chwaląc kogoś innego bądź uważając samą siebie za nieszczęśliwą, prowokuje męża do mówienia o kimś źle. Ty jednak nie daj się zmusić do mówienia źle o kimś, kogo ona chwali, ale znoś wszystko mężnie. Gdybyś słyszał, że służba chwali innych panów, niech cię to nie wzburza, ale trwaj mężnie [przy twoim postanowieniu]. Dom 
cnót, zwłaszcza tych, które ułatwiają wspólną egzystencję, jak np. wzajemne zaufanie ${ }^{88}$.

Przywołując biblijną postać Hioba, Chryzostom przedstawia wpływ żon na postawę mężów. W końcowej partii swej wypowiedzi, podziwiając postawę Hioba stwierdza:

„Skoro żony pobudzają do wielu czynów często nawet takich [mężów], którzy są w dobrym stanie i nie doznają niczego przykrego, to pomyśl, jak silna była dusza [Hioba], gdy odparł niewiastę uderzającą nań z taką bronią i podeptał dwa najsilniejsze uczucia: pożądliwość cielesną i litość" $"$.

Aktywne nabywanie małżeńskiej roztropności czyni z małżonków i rodziny chrześcijańskiej prawdziwy Kościół, gdyż - jak stwierdza złoto-

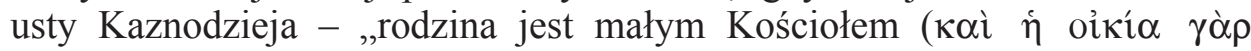

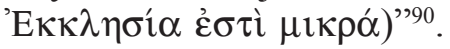

Małżeństwo, pomimo tego, że przysparza wielu trosk, jednak nie powinno stanowić usprawiedliwienia dla duchowego letargu ${ }^{91}$, gdyż rodzina także powinna kształtować duchowość chrześcijańską. Nasz Autor zalecał, aby małżonkowie wspólnie modlili się i razem chodzili na nabożeństwa, a po wysłuchaniu kazania i opuszczeniu kościoła nie wracali do codziennych zajęć, lecz udawali się do domów, by wspólnie z rodziną jeszcze raz rozważyć odczytane w kościele teksty Pisma Świętego oraz to, co zostało powiedziane w kaza$\mathrm{niu}^{92}$. Natychmiastowy powrót do zajęć domowych powodowałby utracenie

niech będzie dla ciebie miejscem walki i palestrą dla cnoty, abyś - tam dobrze się wyćwiczywszy - z wielką zręcznością mógł potykać się z przeciwnikami w rynku. Tak samo postępuj w odniesieniu do próżnej chwały. Jeśli unikać będziesz chwalenia się przed żoną i domownikami, to i wobec innych nie ulegniesz tej słabości. A w każdym przypadku jest to ciężka i tyrańska choroba, szczególnie w obecności żony. Jeśli więc [w domu] zwalczymy jej moc, wówczas również w innych okolicznościach łatwo ją pokonamy. Tak samo postępujmy ze wszystkimi innymi namiętnościami, walcząc z nimi w domu i nacierając się codziennie oliwą".

${ }^{88}$ Por. Joannes Chrysostomus, In epistulam ad Ephesios hom. 20, 6, PG 62, 143, thum. J. Krykowski, BOK 19, 61: „Mąż niech łatwo nie daje wiary oskarżeniom przeciw żonie. Żona niech nie śledzi niemądrze każdego kroku męża, a mąż niech sam nie okazuje się zasługującym na nieufność".

${ }^{89}$ Joannes Chrysostomus, In Matthaeum hom. 33, 7, PG 57, 397, ŹMT 18, 399.

${ }^{90}$ Joannes Chrysostomus, In epistulam ad Ephesios hom. 20, 6, PG 62, 142, BOK 19, 60; zob. Militello, Donna e Chiesa, s. 136 i 142; A Bober, Rodzina kościolem domowym wedtug św. Jana Chryzostoma, VoxP 5 (1985) z. 8-9, 193-200; S. Longosz, Rodzina wczesnochrześcijańska kościołem domowym, RT 51 (2004) z. 10, 36-50.

${ }^{91}$ Por. Joannes Chrysostomus, Catecheses ad illuminandos 7, 28, ed. A. Wenger, SCh 50bis, Paris 1970, 243; In epistulam I ad Corinthios hom. 19, 3, PG 61, 155-156.

${ }^{92}$ Por. Joannes Chrysostomus, In epistulam ad Ephesios hom. 20, 9, PG 62, 147, BOK 19, 67: „Módlcie się wspólnie. Razem chodźcie do świątyni, a w domu rozmawiajcie o tym, co tam było czytane i mówione". W sytuacji, gdy tylko mąż uczestniczył w nabożeństwie, Chryzostom poleca mu, aby po powrocie do domu przywołał do siebie całą rodzinę i powtórzył jej to, co usłyszał w kościele, zob. In Matthaeum hom. 5, 1, PG 57, 55, ŹMT 18, 68: „Nie powinno się od razu po 
duchowej nauki, którą zdobyło się w kościele ${ }^{93}$. Zalecał też, by wspólnie z rodziną czytać Pismo Święte ${ }^{94}$. W ten sposób dom staje się nauczycielem w życiu Kościoła ${ }^{95}$. Niestety, codzienność niesie ze sobą wiele trosk o rozmaite sprawy doczesne, które niszczą to, co się zdobyło w kościele. $Z$ tego względu Jan Chryzostom poleca, by każda rodzina przynajmniej jeden dzień w tygodniu poświęciła na rozważanie spraw duchowych ${ }^{96}$. Podobnie jak w sprawach doczesnych obowiązki publiczne należy wypełnić przed sprawami domowy-

wyjściu z [naszego] zebrania rzucać się ku zajęciom niestosownym dla usłyszanej nauki, lecz przyszedłszy do domu zaraz wziąć księgę do ręki, przywołać żonę i dzieci do uczestnictwa w przypominaniu tego, coś słyszał, a dopiero potem przystąpić do zajęć domowych".

${ }^{93}$ Por. Joannes Chrysostomus, In Genesim hom. 2, 4, PG 53, 51; In Matthaeum hom. 11, 8, PG 57, 202, ŹMT 18, 145: „,byście podziwiając wprawdzie rzeczy tu [tj. w kościele] usłyszane, po powrocie, lekkomyślnie porzuciwszy tablice waszych dusz, nie pozwolili diabłu tego zmazać - niechaj każdy wróciwszy do domu przywoła swą żonę, niech jej to opowie, weźmie ją jako pomocnicę i od dzisiejszego dnia wejdzie do tej pięknej palestry, używając jako oliwy zasobów Ducha".

${ }^{94}$ Por. Joannes Chrysostomus, In Genesim sermo 6, 2, PG 54, 607; In Matthaeum hom. 2, 6, PG 57, 30-32; 5, 1, PG 57, 55; In epistulam ad Ephesios hom. 21, 2, PG 62, 151; De Lazaro 3, 1, PG 48, 991-992, thum. A. Bober, w tegoż, Antologia patrystyczna, Kraków 1965, 95-96: „Dlatego napominam was i proszę nieustannie, żebyście nie tylko tutaj w kościele uważali na to, co się mówi, lecz żebyście również pilnie czytali Pismo Święte w domu. Niech mi tu nikt nie występuje z zimnymi i niemądrymi wymówkami: Jestem adwokatem, radnym, rzemieślnikiem, mam żonę i muszę zarabiać na wyżywienie dzieci, muszę prowadzić dom, jestem człowiekiem świeckim. Nie jest moim obowiązkiem czytanie Pisma Świętego. Niechaj zajmują się tym ci, co usunęli się od świata, co po górach mieszkają i bezustannie żyją w samotności. - Co ty mówisz? Zajmowanie się Pismem Świętym nie jest ponoć twoim obowiązkiem, boś zaplątany w tysiączne kłopoty? Otóż właśnie dlatego powinieneś tym bardziej zainteresować się tym. Albowiem tamci nie potrzebują aż tak bardzo pociechy i pomocy Pisma Świętego, jak ci, których życie codzienne porywa wir przeróżnych zajęć. Właśnie dlatego powinieneś się więcej zająć Pismem Świętym, niż oni. Dla nich bowiem pociecha i pomoc Pisma Świętego nie jest tak konieczna, jak dla tych, co znajdują się w kłębowisku codziennych kłopotów. Do mnichów nie dociera rozgwar uliczny, bo domki pobudowali sobie na odludziu, z nikim się nie stykają, lecz zażywają doskonałego spokoju i ciszy, i czują się całkiem bezpieczni, jakby przybili do osłoniętego od wiatrów portu. My tymczasem jakby na pełnym morzu jesteśmy tam i tam rzucani i obracamy się wśród tysiącznych niebezpieczeństw grzechu, potrzebujemy więc ustawicznie pociechy i zachęty Pisma Świętego. Oni siedzą z dala od boju, dlatego też rzadko otrzymują razy. Ty zaś stoisz na pierwszej linii frontu i nowe rany otrzymujesz bez przerwy. Dlatego potrzebujesz więcej leków”; tamże 3, 1, PG 48, 992 (tłum. własne): „Na przykład twoja żona prowokuje cię, twój syn cię martwi, a niewolnik złości cię, twój wróg spiskuje przeciwko tobie, twój przyjaciel zazdrości ci, twój sąsiad przeklina cię, twój towarzysz broni podstawia ci nogi, często prawo grozi ci procesem, dręczy cię ubóstwo, zasmuca cię utrata własności, powodzenie omija cię, gnębi cię pech, i wiele spraw i obowiązków zniechęca cię i zasmuca, zarozumiałość i rozpacz otacza nas ze wszystkich stron i mnóstwo pocisków spada zewsząd. Ciągle potrzebujemy ochrony, jaką daje nam Pismo Święte". W Antologii patrystycznej zostało błędnie podane, że jest to przekład fragmentu: contio 3, 1-2; w rzeczywistości przekład obejmuje tylko niecały fragment contio 3, 1 .

${ }^{95}$ Por. R.A. Greer, Broken Lights and Mended Lives: Theology and Common Life in the Early Church, University Park (Pennsylvania) 1986, 109-110; R.A. Krupp, Shepherding the Flock of God. The Pastoral Theology of John Chrysostom, New York 1991, 173.

${ }^{96}$ Por. Joannes Chrysostomus, In Matthaeum hom. 5, 1, PG 57, 55, ŹMT 18, 69: „Nadajmy so- 
mi, tak samo w sprawach duchowych, należy najpierw wypełnić obowiązki względem Boga ${ }^{97}$.

Nasz Autor przypomina, że małżonkowie powinni być nawzajem dla siebie i dla pozostałych członków rodziny „pasterzami” dbającymi o dobro „owiec” powierzonych ich pieczy ${ }^{98}$. Zapewnia też, że wzajemna troska domowników będzie prowadzić do zgody i pokoju w rodzinie ${ }^{99}$. Jako przykład wspomina rodzinę Abrahama. Izaak wraz z Sarą oraz trzystu osiemnastu służącymi stanowią przykład wielkiego ładu moralnego i pobożności ${ }^{100}$.

4. Jedność małżonków. Celem duchowym małżeństwa jest realizowanie jedności między małżonkami ${ }^{101}$, co jest urealnieniem jedności Chrystusa (Oblubieńca) i Kościoła (Oblubienicy), oraz duchowym odbiciem rzeczywistości Kościoła ${ }^{102}$. Jednak Antiocheńczyk zwraca uwagę na fakt, że zażyłość małżonków, która jest siłą związku małżeńskiego ${ }^{103}$, w pewnych okolicznościach może stać się źródłem jego słabości, gdyż małżeństwo nieraz komplikowało życie duchowe małżonków i kierowało ich w stronę doczesności ${ }^{104}$.

Przekaz biblijny opowiadający o stworzeniu kobiety (por. Rdz 2, 21-22) stał się dla Chryzostoma przedmiotem szczegółowej analizy filologicznej. Złotousty kaznodzieja zwraca uwagę na „subtelność przekazu biblijnego, opi-

bie, naszym żonom i \{naszym dzieciom\} nienaruszalne prawo, byśmy jeden cały dzień w tygodniu przeznaczali na słuchanie i rozważenie tego, co usłyszeliśmy na zgromadzeniu".

${ }^{97}$ Por. Joannes Chrysostomus, In Matthaeum hom. 77, 6, PG 58, 710, ŹMT 23, 413: „Jeśli w rzeczach doczesnych staramy się spełnić obowiązki publiczne przed sprawami domowymi, $[\ldots]$ tym bardziej należy tak postępować w rzeczach duchowych, aby najpierw wypełnić obowiązki względem Boga - Króla niebieskiego".

${ }_{98}$ Por. Joannes Chrysostomus, In epistulam ad Romanos hom. 29, 5, PG 60, 660-661; In Matthaeum hom. 77, 6, PG 58, 709-710, ŹMT 23, 413: „Każdy z nas ma owcę. Niech ją prowadzi na odpowiednie pastwisko. Mąż, wstawszy rano, niech myśli jedynie o tym, co czynić lub mówić, czym mógłby cały dom uczynić pobożniejszym. Z kolei żona niech jeszcze bardziej troszczy się o to, aby cały dom spełniał uczynki prowadzące do nieba".

${ }^{99}$ Por. Joannes Chrysostomus, In epistulam ad Ephesios hom. 20, 6, PG 62, 143, BOK 19, 60 : „Gdy mąż, żona, dzieci i służba dbają o te rzeczy, wielki pokój panuje w tym domu. A jeśli zabraknie takiego podejścia, nieraz przez jednego złego domownika wszystko upada i zostaje zburzone".

${ }^{100}$ Por. Joannes Chrysostomus, In epistulam ad Ephesios hom. 20, 6, PG 62, 143.

${ }^{101}$ Por. Joannes Chrysostomus, In epistulam ad Ephesios hom. 20, 1, PG 62, 135, BOK 19, 47 : „Nie może bowiem istnieć taka więź między przyjaciółmi, jak między kobietą i mężczyzną, którzy są połączeni prawym węzłem małżeńskim".

${ }^{102}$ Por. Joannes Chrysostomus, In Genesim hom. 56, 1, PG 54, 487.

${ }^{103}$ Por. Joannes Chrysostomus, In epistulam ad Ephesios hom. 20, 1, PG 62, 135-136, BOK 19, 48: „Powstają z tego wielkie problemy i wielkie pożytki, zarówno dla rodzin, jak i dla całych państw. Nic bowiem nie kształtuje tak naszego życia, jak miłość męża i żony. Z powodu tej miłości wielu chwyciło za broń. Wielu za nią życie oddaje”.

${ }^{104}$ Por. Joannes Chrysostomus, In epistulam ad Ephesios hom. 20, 4, PG 62, 140; zob. Krupp, Shepherding the Flock of God, s. 173. 
sującego stworzenie niewiasty" 105 i podkreśla, że autor natchniony w opisie tym

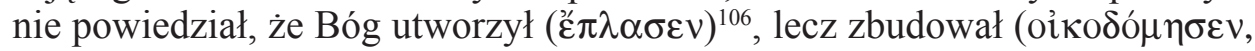

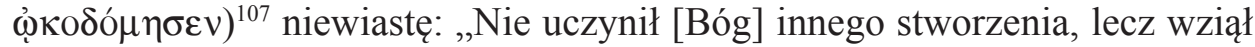
z gotowego już małą cząstkę, z której ukształtował cały organizm" ${ }^{108}$. Słowa te mocno akcentują jedność mężczyzny i kobiety ${ }^{109}$.

W ujęciu Jana Chryzostoma jedność małżonków wyraża się też przez trwałość i nienaruszalność małżeństwa. $Z$ tego względu, przeciwstawiając się powszechnej praktyce rozwodów, na które zezwalało prawodawstwo państwowe ${ }^{110}$, złotousty Kaznodzieja broni jedności i nierozerwalności małżeństwa ${ }^{111}$. Komentując tekst Ewangelii według św. Mateusza (19, 3-9), w którym jest mowa o faryzeuszach pytających Jezusa o możliwość oddalenia żony, nasz Autor podkreśla, że nierozerwalność małżeństwa wynika z faktu stworzenia i zamysłu Boga, który na początku uczynił jednego mężczyznę i jedną kobietę (a nie wiele kobiet). Przez małżeństwo dwoje ludzi staje się ,jednym ciałem”

${ }^{105}$ Dmitruk, Obyczaje weselne i pogrzebowe, s. 265.

${ }^{106}$ Forma ع้ $\pi \lambda \alpha \sigma \varepsilon v$ pochodzi od czasownika $\pi \lambda \alpha \dot{\sigma} \sigma \sigma \omega(\pi \lambda \alpha \dot{\alpha} \tau \tau \omega)$, który przyjmuje następujące znaczenia: „1. tworzyć, kształtować, formować, modelować, lepić; 2. kształtować, urabiać przez wychowanie, ćwiczenie; 3. utworzyć obraz czegoś w myśli, wyobrazić sobie; 4. układać w pewien kształt, nadawać pewien kształt; 5. wymyślić, zmyślić, ukuć" (Stownik grecko-polski, red. Z. Abramowiczówna, III, Warszawa 1962, 545-546); por. G.W.H. Lampe, A Patristic Greek Lexicon, Oxford 1961, 1089: „A. form, mould, fashion; 1. ref. man's creation; 2. ref. spiritual re-creation; B. devise, invent”; H.G. Liddell - R. Scott, Greek-English Lexicon, Oxford 1958, 1412: „I. 1. form, mould, prop. of the artist who works in soft substances, such as earth, clay, wax; Pass., to be moulded, made; 2. plaster; II. generally, mould, form by education, training, etc; III. form an image of a thing in the mind, imagine; IV. put in a certain form; V. metaph. fabricate, forge".

${ }^{107}$ Forma oỉ przyjmuje następujące znaczenia: „I. 1. budować dom, w ogóle budować; 2. układać, drapować; II. met. 1. budować, opierać coś na czymś; 2. w znacz. mor. podnosić, budować, ulepszać" (Abramowiczówna III 249); por. Lampe, s. 939: „1. build, build up; 2. edify; 3. encourage”; LiddellScott, s. 1204: „1. a. build a hause: generally, build; b. generally, fashion; 2. metaph., build or found upon; 3. metaph., build up, edify".

${ }^{108}$ Joannes Chrysostomus, In Genesim hom. 15, 3, PG 53, 122; zob. Dmitruk, Obyczaje weselne i pogrzebowe, s. 265.

${ }^{109}$ Por. Dmitruk, Obyczaje weselne i pogrzebowe, s. 265.

${ }^{110}$ Por. A. Młotek, Nierozerwalność matżeństwa w nauczaniu Ojców Kościoła, CS 10 (1978) 182-183.

${ }^{111}$ Por. Joannes Chrysostomus, In epistulam I ad Corinthios hom. 19, 2, PG 61, 154. Również ustawodawstwo kościelne środowiska antiocheńskiego potwierdza nierozerwalność małżeństwa; zob. Constitutiones Apostolorum VI 14, 4, ŹMT 42, 152: „Po zawarciu małżeństwa nie wolno oddalić małżonki, jeśli jest bez zarzutu. [...] Żona jest bowiem towarzyszką życia, złączoną przez Boga, aby dwoje stanowili jedno ciało, kto zaś ponownie dzieli jedno na dwoje, jest wrogiem Bożego stworzenia oraz nieprzyjacielem Bożej opatrzności. Tak samo ten, kto bierze sobie kobietę zepsutą i przekraczającą prawo natury, jest nieprawy, ponieważ «kto trzyma nierządnicę, głupi jest i bezbożny» (Prz 18, 22), i powiedziano: «odetnij ją od swego ciała» (Syr 25, 26). Kobieta bowiem, która zwraca się ku innemu, nie jest pomocą (por. Rdz 2, 18; Tb 8, 6), lecz zdradą". 
(Mt 19, 5), którego nie można rozdzielać. Chryzostom w jasnych słowach wyraża tę prawdę:

„Jak więc zbrodnią jest ciąć ciało, tak samo nieprawością - opuścić żonę"112.

Ponadto podkreśla, że rozwód, który jest rozerwaniem jedności małżeń-

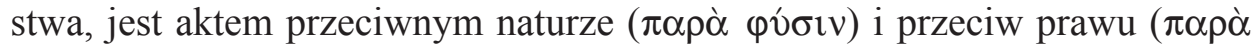
vó $\mu \mathrm{ov})^{113}$. Z tego względu występuje przeciw ustawodawstwu cywilnemu, które - w przeciwieństwie do kanonów prawa kościelnego - zezwalało na rozwód i rozejście się małżonków ${ }^{114}$.

Innym wymiarem realizacji jedności miedzy mężem i żoną jest ich współżycie, o czym była już mowa w punkcie pierwszym niniejszego opracowania, dotyczącym innego celu małżeństwa, jakim jest trwanie w czystości.

$* * *$

W podsumowaniu należy zauważyć, że Jan Chryzostom wskazując istotne cele małżeństwa, na pierwszy plan wysuwał wartości duchowe. Człowiek, jako istota stworzona na obraz i podobieństwo Boga (por. Rdz 1, 27) powinien dążyć do upodobnienia się do swego Stwórcy przez święte życie. Jedną z najpoważniejszych przeszkód stających na drodze do świętości jest ludzka seksualność, a zwłaszcza pożądliwość. Z tego względu Antiocheńczyk postrzegał małżeństwo przede wszystkim jako „lekarstwo” na pożądliwość, środek ułatwiający życie w czystości oraz przyjazne środowisko nabywania cnót chrześcijańskich. W dalszej kolejności nasz Autor zwracał uwagę na wymiar praktyczny instytucji małżeństwa podkreślając takie jego cele jak: zrodzenie potomstwa - dzięki któremu małżonkowie mogą cieszyć się przedłużeniem swej egzystencji i zapewnić ciągłość rodzaju ludzkiego; wzajemną pomoc, odnoszącą się do wszystkich wymiarów ludzkiego życia, dzięki której małżonkowie nawzajem wspierają się w realizacji wspólnych celów (przede wszystkim w dążeniu do świętości); oraz jedność małżonków wyrażającą się w trwałości i nienaruszalności związku małżeńskiego, w którym mężczyzna i kobieta stają się ,jednym ciałem" (por. Mt 19, 5; Mk 10, 8).

${ }^{112}$ Joannes Chrysostomus, In Matthaeum hom. 62, 2, PG 58, 597, ŹMT 23, 247.

${ }_{113}$ Joannes Chrysostomus, In Matthaeum hom. 62, 2, PG 58, 597.

114 Por. Joannes Chrysostomus, Quales ducendae sint uxores 1-2, PG 51, 226-227; In illud: „Propter fornicationes unusquisque suam uxorem habeat” 4, PG 51,213-214; zob. Militello, Donna e Chiesa, s. 133. 
LES OBJECTIFS DU MARIAGE CHRETIEN CHEZ JEAN CHRYSOSTOME

\section{(Résumé)}

Soulignant les objectifs essentiels du mariage, Jean Chrysostome accentue plus spécifiquement ses valeurs spirituelles. Comme un être créé à l'image de Dieu (Genèse 1,27), l'homme devrait aspirer à s'assimiler à son Créateur par une vie sainte. La sexualité de l'homme, et plus précisément le désir, est un des obstacles les plus difficiles sur la route vers la sainteté. Pour cette raison, le prédicateur d'Antioche considère le mariage surtout comme un " médicament » contre le désir, un remède qui arrange la vie en pureté et l'entourage convenable à acquérir les vertus chrétiennes. Notre auteur met ensuite l'accent sur l'aspect pratique de l'institution du mariage, en soulignant de tels objectifs comme : le fait de mettre au monde les enfants, grâce auquel les époux peuvent se réjouir de la prolongation de leur existence et garantir la durée du genre humain ; l'aide mutuelle qui se rapporte à tous les aspects de la vie humaine et grâce à laquelle les époux s'entraident dans la réalisation des objectifs communs (surtout dans la route vers la sainteté) ; et l'union des époux qui apparaît dans la stabilité et invulnérabilité du mariage dans lequel un homme et une femme deviennent « une seule chair » (cf. Matthieu 19, 5 ; Marc 10, 8). 
